\title{
Quarter-Level Analysis of Subclinical and Clinical Mastitis in Primiparous Heifers Following the Use of a Teat Sealant or an Injectable Antibiotic, or Both, Precalving
}

\author{
K. I. Parker, ${ }^{, 1}$ C. W. R. Compton, ${ }^{*}$ F. M. Anniss, ${ }^{*}$ C. Heuer, $\dagger$ and S. McDougall ${ }^{*}$ \\ ${ }^{*}$ Animal Health Centre, PO Box 21, Morrinsville, New Zealand \\ †Epicentre, Massey University, Palmerston North, New Zealand
}

\section{ABSTRACT}

This study investigated the effect of infusion of a bismuth subnitrate teat canal sealant or an injectable antibiotic, or both, in heifers on the cure of existing intramammary infection (IMI), incidence of new IMI, prevalence of postcalving IMI, and incidence of clinical mastitis in the first 2 wk postcalving at the quarter level. Heifers ( $\mathrm{n}=1,067)$ in 30 seasonally calving, pasture-fed dairy herds were randomly assigned at the heifer level to 1 of 4 treatments (no treatment; 3 intramuscular injections of $5 \mathrm{~g}$ of tylosin antibiotic at 24-h intervals; infusion of a teat sealant into all 4 quarters; 3 intramuscular injections of $5 \mathrm{~g}$ of tylosin antibiotic and infusion of teat sealant into all 4 quarters). Mammary gland secretion samples were collected from each quarter of every heifer before treatment. Heifers within a herd were enrolled on one calendar day, $27 \mathrm{~d}$ (on average) before the planned start of the seasonal calving period. Duplicate milk samples were collected from each gland within $5 \mathrm{~d}$ after calving for bacterial culture and from glands the herdowners diagnosed as having clinical mastitis. The relative risk of effect of treatment on the incidence of cure, incidence of new IMI, prevalence of postcalving IMI, and incidence of clinical mastitis were calculated at the gland level using multivariate logistic regression analyses. Neither infusion of a teat sealant nor treatment with the injectable antibiotic increased the cure of precalving IMI. Infusion of the teat sealant reduced the risk of new IMI with any pathogen by $74 \%$, reduced the prevalence of postcalving IMI by $65 \%$, reduced the risk of new infection with Streptococcus uberis by $70 \%$ in quarters with an IMI precalving, and reduced the incidence of clinical mastitis from which a pathogen was isolated by $70 \%$ in quarters with an IMI precalving. Parenteral antibiotic treatment had no effect on any of these outcomes. In conclusion, use

Received March 20, 2007.

Accepted October 2, 2007.

${ }^{1}$ Corresponding author: kparker@ahc.co.nz of an internal teat-canal sealant in heifers reduced the postcalving IMI prevalence and the incidence of pathogen-associated clinical mastitis postcalving by decreasing the incidence of new infections over this high-risk peripartum period, and may be a useful tool for reducing the risk of mastitis in heifers.

Key words: mastitis, heifer, teat sealant, antibiotic

\section{INTRODUCTION}

The incidence of clinical mastitis and IMI in firstcalving heifers peripartum is high relative to that in multiparous cows (Pankey et al., 1991; Barkema et al., 1998; Barnouin and Chassagne, 2001). Pankey et al. (1996) reported that an average $8.1 \%$ of heifers in 11 pasture-grazed New Zealand dairy herds were diagnosed with clinical mastitis within $5 \mathrm{~d}$ after calving, and that the environmental pathogen Streptococcus uberis was isolated from $67.6 \%$ of these cases.

Bacteria have been isolated from the mammary gland in heifers as early as 9 mo precalving (Trinidad et al., 1990a), and the prevalence of infection increases as calving approaches (Oliver and Mitchell, 1983; Aarestrup and Jensen, 1997), with prevalences reported to range from 20 to $97 \%$ in heifers precalving (Trinidad et al., 1990a; Myllys, 1995). Parker et al. (2007) found the gland-level prevalence of IMI $\sim 30 \mathrm{~d}$ precalving in primiparous heifers in New Zealand to be $15.5 \%$. There is an increased risk of new IMI and clinical mastitis peripartum relative to the earlier gestational period, associated with the transition into lactation (Aarestrup and Jensen, 1997).

The relative prevalence of specific pathogens changes across the peripartum period (Oliver and Mitchell, 1983; Aarestrup and Jensen, 1997). Glands may change IMI status by acquiring a new IMI or undergoing spontaneous cure of an existing IMI precalving (Aarestrup and Jensen, 1997). The effect of the presence of an existing IMI precalving on the risk of a new IMI is still unclear. Some studies in multiparous animals have shown that existing IMI with a minor pathogen may reduce the prevalence of IMI with major pathogens at 
calving and in early lactation (Rainard and Poutrel, 1988; Lam et al., 1997; Green et al., 2002). Other studies, however, have found that an existing IMI with a minor pathogen increases the risk of infection with another pathogen (Pankey et al., 1985; Hogan et al., 1988).

Specific prevention programs for mastitis in dairy heifers are limited. Current mastitis prevention is targeted at multiparous animals, which primarily focuses on prevention of spread and elimination of the contagious pathogens (Woolford et al., 1995). Clinical mastitis in heifers occurs primarily early in lactation (Barkema et al., 1998) and, in pasture-grazing systems, is commonly caused by the environmental pathogen Strep. uberis (Pankey et al., 1996; McDougall, 1999); hence, programs that are effective at reducing mastitis in cows in lactation may not be effective for heifers in the periparturient period.

Infusion of intramammary antibiotics precalving reduces the prevalence of IMI and the incidence of clinical mastitis postcalving in heifers (Oliver et al., 1992, 1997). Use of antibiotics, may, however increase the risk of residues in milk, and new infections may still be acquired before calving, because the period over which the antibiotics remain above the MIC in the glands is highly variable between heifers (Trinidad et al., 1990b; Oliver et al., 1992).

In seasonally calving dairy herds, intramammary administration of antibiotics to every gland of every heifer presents logistical problems because of the large numbers of animals calving in a short period and thus needing to be treated. Parenteral antibiotic therapy has been successfully used in treating clinical and subclinical mastitis in lactating cows (Ziv and Storper, 1985; StRose et al., 2003), and may be more easily administrated to heifers precalving than intramammary therapy. The macrolide antibiotic tylosin has been used to treat clinical mastitis in dairy cows (McDougall et al., 2007) because it is lipid soluble and is a weak base, which results in high intramammary concentrations. The milk and meat withholding period requirements for human consumption for the antibiotic must be met when it used precalving. Therefore, these withholding periods must be considered in the timing of administration and choice of antibiotic.

The infusion of a teat sealant into the teat canal at the end of lactation has been shown to reduce the incidence of new IMI during the dry period of multiparous cows (Meaney, 1977; Woolford et al., 1998; Huxley et al., 2002). In a pilot study, infusion of a teat sealant approximately 4 to $6 \mathrm{wk}$ before calving was found to be effective at decreasing the prevalence of postcalving (0 to 4 d) IMI of Strep. uberis in heifers by $84 \%$ (Parker et al., 2007). The pilot study had limited statistical power, and a larger field study was required to confirm these preliminary findings.

Therefore, the hypotheses of this study were that the infusion of a teat sealant or treatment with tylosin, or both in heifers approximately $30 \mathrm{~d}$ before their planned start of calving in seasonal-calving dairy herds would result in 1) an increased cure proportion of existing IMI between the precalving treatment and 0 to $5 \mathrm{~d}$ postcalving; 2) a reduction in the number of new quarter-level IMI of any bacteria between precalving treatment and 0 to $5 \mathrm{~d}$ postcalving; 3 ) a reduction in the number of new quarters infected with Strep. uberis between the precalving treatment and 0 to $5 \mathrm{~d}$ postcalving; 4) a reduction in the prevalence of quarter-level IMI between $d 0$ and 5 postcalving; and 5) a reduction in the incidence of quarter-level clinical mastitis up to 14 d postcalving.

\section{MATERIALS AND METHODS}

Heifers $(n=1,067)$ in 30 spring-calving, pasture-fed dairy herds were enrolled in this prospective intervention study. The herds were located in the Waikato region of the North Island of New Zealand. Between 18 and 48 heifers were enrolled from each herd. The herds ranged from 214 to 810 cows (mean $=347, \mathrm{SD}=139$ ). Herds were selected on the basis that herdowners 1) would undertake 4 herd tests for milk production and composition in the season of the study; 2) used an electronic database (Livestock Improvement Corporation, Hamilton, New Zealand) to record animal details; 3) were located within a radius of $30 \mathrm{~km}$ of Morrinsville, New Zealand; 4) maintained high-quality cow records; and 5) agreed to comply with the trial protocol.

A priori, a sample size of 1,000 heifers was calculated based on the assumption that the gland-level prevalence of IMI postcalving would be decreased by the teat sealant and antibiotic treatment using an absolute effect size of 5\% (Hintze, 2001). A preliminary study estimated gland-level prevalence of IMI to be approximately $16 \%$ precalving and $12 \%$ postcalving. Teat sealant reduced the prevalence of postcalving IMI from approximately 12.1 to $9.7 \%$ (Parker et al., 2007). Hence, to demonstrate a $5 \%$ difference [with a $95 \%$ confidence limit ( $\alpha=0.05)$ and $80 \%$ power $(\beta=0.2)$ ] in postcalving prevalence, with the control group having an incidence of $10 \%$, then 474 glands per group were required. Approximately twice that number of glands was enrolled per group to account for the potential clustering of mastitis within heifer and heifer within herd.

Heifers in each herd were enrolled on one calendar day at a median of $27 \mathrm{~d}$ before the start of the seasonal calving period. The heifers calved between 5 and 127 $\mathrm{d}$ after enrollment (median $=39 \mathrm{~d}$ ). Treatment was 
assigned at the heifer level within herd. Each heifer was randomly assigned to a treatment using a random number generator function ( $R$ Development Core Team, 2006), and the farmers were blinded to the treatment.

Before treatment, each teat-end was scrubbed with a cottonwool pledget moistened in $70 \%$ methanol and a gland secretion sample was collected aseptically $(\mathrm{n}=$ 4,268 glands). No secretion was discarded before collection because there was only a small total volume of secretion present in most glands. If no secretion could be collected from a gland, it was recorded as a missing sample ( $\mathrm{n}=99$ glands).

Following sampling, all 4 glands within a heifer were infused with $2.6 \mathrm{~g}$ of bismuth subnitrate following teatend scrubbing ( $\mathrm{n}=268$ heifers; Teat Seal, Pfizer Animal Health NZ Ltd., Auckland, New Zealand), or a heifer was administered with $5 \mathrm{~g}$ of tylosin base i.m. for $3 \mathrm{~d}$ at 24-h intervals ( $n=268$ heifers; Tylan 200, Elanco Animal Health, Manukau City, New Zealand), or all 4 glands were infused with the teat sealant and the heifer was administered $5 \mathrm{~g}$ of tylosin base i.m. for $3 \mathrm{~d}$ at 24 $h$ intervals ( $n=266$ heifers), or they were left as an untreated control ( $n=265$ heifers). The tip of the teatsealant cannula was inserted approximately $3 \mathrm{~mm}$ into the teat canal for infusion. Following sampling or infusion, $0.5 \%$ effective iodine was applied by manual spraying to all teat ends. Technicians administered the first treatment of tylosin and then left labeled doses of tylosin for the remaining 2 treatments for farm staff to administer.

The BCS (on a 1-to-10 scale in half-score increments; Roche et al., 2004), the udder and escutcheon hygiene score (on a 1-to-4 scale; Schreiner and Ruegg, 2003), the length of the tail of each heifer was recorded on an ordinal scale as: $1=$ docked short $(<20 \mathrm{~cm}$ in total length); 2 = docked medium length (20 to $40 \mathrm{~cm}$ total length); 3 = natural length but with the twitch trimmed; 4 = natural length and untrimmed; and presence of udder edema (yes or no; as determined by digital pressure in the caudal aspect of the udder resulting in the presence of a depression for $>30 \mathrm{~s}$ ) were recorded for each animal at enrollment and again at the postcalving sampling. Additionally, the distance from the ground to the lowest front teat within a heifer ("teat height") was measured at the time of the postcalving sampling.

Within $5 \mathrm{~d}$ of calving (range 0 to $5 \mathrm{~d}$ after calving; median $=2 \mathrm{~d})$, duplicate milk samples $(\sim 5 \mathrm{~mL}$ each $)$ were collected from each gland for bacteriological analysis, following aseptic preparation of the teat end and discard of the first 3 strippings. Herdowners were asked to diagnose clinical mastitis based on the presence of visible changes (e.g., clots or discoloration) in the milk or swelling/pain in the gland. Duplicate milk samples $(\sim 5 \mathrm{~mL}$ each) were collected by technicians from glands that were diagnosed with clinical mastitis within $14 \mathrm{~d}$ of calving, following aseptic preparation of the teat end and discard of the first 3 strippings. When clinical mastitis was diagnosed on or before the scheduled 0- to 5$\mathrm{d}$ postcalving visit, all glands, including the gland with clinical mastitis, were sampled and the bacteriology results were included in both the postcalving 0 to 5 $\mathrm{d}$ analysis (postcalving IMI) and the clinical mastitis analysis. Calving date and breed data were retrieved from the national database (Livestock Improvement Corporation).

The experimental procedures and animal conditions were approved by the Animal Ethics Committee (\# 10134), AgResearch (Hamilton, New Zealand).

\section{Bacteriology}

Precalving secretion samples, duplicate postcalving milk samples, and duplicate clinical mastitis milk samples were processed for bacteriology within $24 \mathrm{~h}$ of collection following storage at $4^{\circ} \mathrm{C}$. Microbiological procedures, diagnosis of IMI, and categorization of results were undertaken using standard methodology with minor modifications (National Mastitis Council, 1999). Following gentle inversion at room temperature, $10 \mu \mathrm{L}$ of milk was streaked onto a quadrant of a $5 \%$ sheep blood agar plate containing $0.1 \%$ esculin (Fort Richard, Auckland, New Zealand), and incubated at $37^{\circ} \mathrm{C}$ for 48 $\mathrm{h}$. The genus of bacteria was provisionally determined on the basis of colony morphology, Gram stain, hemolysis pattern, catalase test, and esculin reaction. Grampositive, catalase-positive isolates were further tested using a tube-coagulase test (BBL Staphyloside Latex tube-coagulase test, Becton Dickinson, Sparks, MD); coagulase-positive isolates were defined as Staphylococcus aureus and coagulase-negative isolates as CNS. Gram-positive, catalase-negative isolates were CAMPtested: esculin-positive and CAMP-positive or negative isolates were defined as Strep. uberis; esculin-negative and CAMP-negative isolates were defined as Streptococcus dysgalactiae; and esculin-negative and CAMPpositive isolates were defined as Streptococcus agalactiae. Gram-negative rods were subcultured on MacConkey agar (Fort Richard, Auckland, New Zealand), had an oxidase test performed, and were cultured in triplesugar iron agar (Fort Richard) and Simmons citrate agar (Fort Richard). Gram-negative rods that could be identified were recorded, and unidentified organisms were recorded as gram-negative rods. Corynebacterium spp. were defined as small gram-positive rods organized in distinctive "pallisades".

A greater prevalence of gram-negative pathogens may have been isolated using different culture techniques. However, it is unlikely that this would have 
substantially changed the inferences because the change in absolute prevalence of gram-negative pathogens would likely be $<1.5 \%$ even if the sensitivity of the laboratory techniques used were only 50\%. Different culture techniques may increase the sensitivity of detection of some bacterial species, but reduce sensitivity of detection of others. Previous studies suggest that the incidence of clinical mastitis caused by Escherichia coli and other gram-negative pathogens is much lower under New Zealand pasture management systems than in other production systems (Pankey et al., 1996; McDougall et al., 2007).

A milk sample was defined as contaminated if $>2$ distinct colony types were present. Therefore, when a milk sample was contaminated, the result recorded in the duplicate milk sample collected from that quarter was used. The agreement of duplicate milk samples was $98.6 \%$ across a random sample of 1,008 duplicate samples, with the 14 inconsistencies occurring when one sample was contaminated and the other sample cultured a pure growth of bacteria.

A gland was defined as infected when both of the milk samples had 3 or more of each of 1 to 2 colony morphology types present, except for Staph. aureus, when the presence of 1 colony was defined as an infection. The rationale for using a different cut-point in terms of colony-forming units for Staph. aureus than for other pathogens (i.e., $1 \mathrm{vs.} 3 \mathrm{cfu} / 0.01 \mathrm{~mL}$ ) was that the greater cut-point for non-Staph. aureus isolates reduced the risk of a false-positive diagnosis of IMI associated with a single colony of, for example, yeast or Bacillus spp. that may be present due to the less-than-optimal conditions that inevitably occur under field conditions. Conversely, the presence of a single colonyforming unit of Staph. aureus was likely to be significant given that Staph. aureus is predominantly a "cow parasite" bacterium and it has shown that shedding of Staph. aureus may be intermittent (Sears et al., 1990).

\section{Data Handling}

Data from samples and measurements that were collected outside the protocol (i.e., $>5 \mathrm{~d}$ postcalving for the routine postpartum sampling ( $\mathrm{n}=13$ heifers, 52 glands) or $>14 \mathrm{~d}$ postpartum for the clinical mastitis cases) were discarded from the analyses. Twelve heifers did not calve ( $\mathrm{n}=48$ glands) and 1 heifer was not sampled postcalving ( $\mathrm{n}=4$ glands). The data analyzed included 4,164 glands from 1,041 heifers.

Contaminated samples were not included in the denominator when proportions were calculated. A new infection was defined as occurring when a bacterial species was isolated from a gland postcalving that had not been isolated precalving. Cure was defined as occurring when a gland from which a bacterial species was isolated precalving either did not isolate any bacteria or isolated a different bacterial species from the precalving species. A gland could therefore undergo both a cure and develop a new IMI.

When 2 bacterial species were isolated, the gland was defined as infected with 1 pathogen for subsequent analysis. When a "major" pathogen (i.e., Staph. aureus, Strep. uberis, Strep. dysgalactiae, Klebsiella spp., E. coli) and a "minor" pathogen (i.e., CNS or Corynebacterium spp.) were isolated, then the gland was assigned as infected with the major pathogen. When 2 minor pathogens were present, the gland was assigned as infected with CNS, if present. There were 10 quarters across all milk samples in which 2 major pathogens were isolated. In 8 of these samples, $E$. coli was isolated, and the other pathogen type present was assigned to the gland. For the 2 remaining samples, the gland was assigned as infected with Staph. aureus.

\section{Data Analysis}

Analysis was performed at the gland level, because the proposed method of actions of the treatments (teat sealant and antibiotic) were at the gland level; that is, prevention of new IMI and cure of existing IMI. Continuous variables that were normally distributed remained as continuous variables in the subsequent analysis. If the relationship between this continuous variable and the outcome variable was not linear, the variable was categorized or transformed. Body condition score postcalving was categorized into 5 groups $(<4.5,4.5,5,5.5,>5.5)$. Breed of heifer was defined as the predominant parentage breed if greater than 11/ 16th (Friesian or Jersey), with all remaining animals classified as crossbreeds.

Dependent variables (all binary) included cure proportion of IMI, the prevalence of postcalving IMI, incidence of clinical mastitis, incidence of clinical mastitis from which any pathogen was cultured, new IMI with any pathogen, and new IMI with Strep. uberis. A high prevalence of clinical mastitis milk samples from which no pathogens were isolated was found in a pilot study (47.6\% in glands treated with teat sealant; Parker et al., 2007). Because of this finding, analyses of "all" clinical mastitis cases as well as clinical mastitis from which bacteria were isolated were undertaken. Clinical mastitis (including those cases from which no pathogen was isolated) was only analyzed at the bivariate level, because the multivariate models were unstable.

Fixed effects that were examined in the final models were the categorical variables: infusion of a teat sealant, treatment with tylosin, breed, precalving IMI (present/absent), presence of udder edema postcalving 
(binomial; present or absent) and BCS at 0 to $5 \mathrm{~d}$ postcalving, and the continuous variables: interval between treatment or infusion and calving (d), number of days postcalving at sample collection ( 0 to $5 \mathrm{~d}$ ), and the minimum height $(\mathrm{cm})$ of the teat end from the ground. There was no interaction between teat sealant and tylosin in any of the models and so analysis was performed with the 2 main treatment effects coded as infusion of teat sealant (yes or no) and treatment with tylosin (yes or no).

Bivariate associations between independent and dependent variables were examined using $\chi^{2}$ analysis, and crude relative risks (RR) were calculated. If the treatment did not significantly affect the outcome variable at the bivariate level, further modeling was not performed and the bivariate $R R$ was reported. The Mantel-Haenszel procedure was used to stratify the data by precalving IMI, because it was hypothesized that precalving IMI may affect the outcomes, and the adjusted RR were calculated. Predictor variables from the bivariate and stratified analyses associated with the outcome variables (i.e., $P<0.2$ ) were manually added in a forward step-wise manner to the generalized mixed log binomial model (GLIMMIX, version 9.1; SAS Institute, Cary, NC). The variables were added to the model and tested in descending order of significance at the bivariate level. Variables were included in the mixed models if they reached significance or were integral to the study design (i.e., the main treatment effects). Biologically meaningful interactions were evaluated including teat sealant by precalving IMI status, teat sealant by calving to sampling time, and teat sealant by postcalving udder edema. If the interaction was not significant and it did not alter the coefficient of the main effects by $>10 \%$, then the interaction was not included in the final model. Some covariates remained in the model although they were not confounders (i.e., did not alter the main effect coefficients by $>10 \%$ ) because they explained a large amount of variation in the model, improved the model fit (i.e., reduced the model deviance), or because it was biologically plausible to include them. The -2 log likelihood (model deviance), type 3 sums of squares, and the coefficients and error terms of the main effects were also used to determine which variables were included in the final model. Model diagnostics were performed, including plotting the residuals against the predicted values and investigating the outliers.

When the prevalence of a disease outcome is $>10 \%$, odds ratios (OR) overestimate the size of the effect and $R R$ is a better estimate of the effect size (Dohoo et al., 2003; McNutt et al., 2003). Logistic regression models, which use a logit link function (in SAS software) produce coefficients that, when exponentiated, produce
OR. Exponentiation of coefficients from log-binomial models that use the log link function (in SAS software) produce estimates which exponentiate to RR (McNutt et al., 2003), which are reported.

Because glands within heifers are not biologically independent and treatments were assigned at heifer level, the degree of correlation of results between glands within heifers, and between heifers within herds needed to be examined (McDermott et al., 1994; Barkema et al., 1997). The intraclass correlation (ICC) of gland within heifer and heifer within herd were calculated using 1-way ANOVA for each dependent variable (i.e., ICC $>0.2$ ). Therefore, in the final multivariate models, herd was included as a random effect to account for correlation within herds, and heifer nested within herd was included as a random effect statement to account for correlation within heifer (i.e., the final models were "mixed" models).

The only final multivariate model that was not a mixed model was that with the outcome variable being new infection with Strep. uberis. Inclusion of the random effect statements for herd and heifer nested within herd resulted in an unstable model. This was because there were a large number of herds with no new infection of Strep. uberis in either the teat sealant or the nonteat sealant-treated quarters (i.e., some cells were $=0$ ). A marginal binomial logistic regression model (PROC GENMOD, SAS Institute) was used, with herd included as a fixed effect and a compound symmetry repeated statement included for cow to account for correlation within cow for this outcome. This model was not overdispersed (overdispersion $=$ deviance/degrees of freedom $>1$ ), which supports the use of this model (Zadoks et al., 2001). The coefficients of this logistic regression model were exponentiated to give the OR. The quarterlevel incidence of new infection with Strep. uberis across all herds was 5.7\%; hence, OR were an acceptable approximation of RR in this case (McNutt et al., 2003).

Relative risks reported were from the multivariate models, unless otherwise stated. Statistical significance was taken for $P<0.05$, and confidence intervals $(\mathbf{C I})$ reported are for a $95 \%$ range of values. Data were recorded in an Access database (Microsoft, Redmond, WA), and statistical analysis was carried out using SAS version 9.1 (SAS Institute).

\section{RESULTS}

The gland-level prevalence of precalving IMI was $16.8 \%$ and differed between herds $(P<0.001)$. Coagulase-negative staphylococci were the most commonly isolated pathogens (75.5\% of glands with IMI) and Strep. uberis the next most common (15.6\%; Table 1). The prevalence or relative prevalence of bacterial spe- 
Table 1. Number (n) and percentage (\%; within treatment) of bacterial species isolated from mammary gland secretions of heifers collected, on average, $27 \mathrm{~d}$ before calving

\begin{tabular}{|c|c|c|c|c|c|c|c|c|c|c|}
\hline \multirow[b]{3}{*}{ Isolate } & \multicolumn{8}{|c|}{ Treatment $^{1}$} & & \\
\hline & \multicolumn{2}{|c|}{ Teat sealant } & \multicolumn{2}{|c|}{ Tylosin } & \multicolumn{2}{|c|}{$\begin{array}{l}\text { Teal sealant and } \\
\text { tylosin }\end{array}$} & \multicolumn{2}{|c|}{ Control } & \multicolumn{2}{|c|}{ Total } \\
\hline & $\mathrm{n}$ & $\%$ & $\mathrm{n}$ & $\%$ & $\mathrm{n}$ & $\%$ & $\mathrm{n}$ & $\%$ & $\mathrm{n}$ & $\%$ \\
\hline Streptococcus uberis & 27 & 2.7 & 20 & 2.0 & 25 & 2.5 & 32 & 3.3 & 104 & 2.6 \\
\hline Staphylococcus aureus & 4 & 0.4 & 2 & 0.2 & 3 & 0.3 & 8 & 0.8 & 17 & 0.4 \\
\hline CNS & $108[19]^{2}$ & 11.0 & $154[18]$ & 15.4 & 143 [17] & 14.3 & $167[16]$ & 17.0 & $572[70]$ & 14.4 \\
\hline Other major pathogen ${ }^{3}$ & 7 & 0.7 & 8 & 0.8 & $4[1]$ & 0.4 & 7 & 0.7 & $26[1]$ & 0.7 \\
\hline Other minor pathogen ${ }^{4}$ & 5 & 0.5 & 4 & 0.4 & $3[1]$ & 0.3 & $7[1]$ & 0.7 & $19[2]$ & 0.5 \\
\hline No growth ${ }^{5}$ & 851 & 86.6 & 827 & 82.9 & 838 & 84.1 & 778 & 79.2 & 3,294 & 83.2 \\
\hline Contaminated & 27 & 2.6 & 27 & 2.6 & 46 & 4.4 & 38 & 3.7 & 138 & 3.3 \\
\hline No sample & 18 & 1.8 & 24 & 2.3 & 9 & 0.9 & 16 & 1.5 & 67 & 1.6 \\
\hline Total IMI & 151 & 15.4 & 188 & 18.9 & 178 & 17.9 & 221 & 22.5 & 738 & 18.6 \\
\hline Total & 1,028 & & 1,048 & & 1,052 & & 1,036 & & 4,164 & \\
\hline
\end{tabular}

${ }^{1}$ Glands were infused with an intramammary teat sealant into all 4 glands (teat sealant; Teat Seal, Pfizer Animal Health NZ Ltd., Auckland, New Zealand), or treated with injectable tylosin (5 g for $3 \mathrm{~d}$ at 24-h intervals; Tylan 200, Elanco Animal Health, Manukau City, New Zealand), or treated with injectable tylosin ( $5 \mathrm{~g}$ for $3 \mathrm{~d}$ at 24 -h intervals) and infused with an intramammary teat sealant into all 4 glands (teat sealant and tylosin) or nothing (control).

${ }^{2}$ Values in brackets indicate the number of glands from which this species was isolated as the second isolate from that gland.

${ }^{3}$ Other major pathogens $=$ Streptococcus dysgalactiae, Streptococcus agalactiae, Klebsiella spp., Pasturella spp., Enterococcus spp., and Escherichia coli.

${ }^{4}$ Other minor pathogens = Corynebacterium spp., yeasts, gram-negative and gram-positive rods.

${ }^{5}$ No growth $=<3$ colonies cultured or Bacillus or fungi.

cies present precalving did not differ between treatments. The distributions of bacterial species isolated from glands postcalving and from glands with clinical mastitis are shown in Tables 2 and 3, respectively.

The ICC were calculated for each outcome variable within heifer and within herd. The postcalving IMI ICC within heifer was 0.31 , almost 4 times greater than the correlation within herd $(\mathrm{ICC}=0.08)$.

\section{Effect of Treatment on Cure of Existing IMI}

Neither the infusion of a teat sealant [254/2,084 $(12.2 \%)$ vs. $257 / 2,080(12.4 \%), \mathrm{RR}=0.99, P=0.9]$ nor the administration of tylosin [256/2,100 (12.2\%) vs. $255 /$ $2,064(12.4 \%), \mathrm{RR}=0.99, P=0.87]$ altered the proportion of quarters that underwent bacteriological cure.

\section{Effect of Treatment on Prevalence of IMI Postcalving}

The postcalving IMI gland prevalence for the control group was $21.2 \%$ (Table 2), which also differed between herds $(P<0.001)$. The use of a teat sealant precalving decreased the prevalence of any IMI postcalving [154/ $2,080(7.4 \%)$ vs. $458 / 2,084(22.0 \%) \mathrm{RR}=0.35 ; 95 \% \mathrm{CI}=$ $0.28-0.4 ; P<0.001$; Table 4]. Tylosin treatment did not affect the prevalence of IMI postcalving $(\mathrm{RR}=1.02$; $95 \% \mathrm{CI}=0.82-1.27 ; P=0.84)$. Presence of precalving IMI was associated with an increased prevalence IMI postcalving $(\mathrm{RR}=3.25 ; 95 \% \mathrm{CI}=2.82-3.74 ; P<0.001)$. There was no significant interaction present between presence of precalving IMI and teat sealant in this model $(P=0.09)$. Jerseys had a lesser prevalence and Friesians a greater prevalence of IMI postcalving relative to crossbreds (Table 4). There was an inverse relationship between the time between calving and sampling and the risk of isolating an IMI (Table 4, Figure $1 ; P<0.001)$. Lower BCS was associated with decreased prevalence of IMI (Table 4; $P<0.04$ ). Increasing distance of the teat end from the ground was associated with a decreased risk of IMI (Table $4 ; P=0.01$ ).

\section{Effect of Treatment on Incidence of New IMI}

The incidence of new infection with any bacterial species was $15.7 \%$ in the control group Teat sealant decreased the incidence of new IMI with any bacteria $(\mathrm{RR}=0.34 ; 95 \% \mathrm{CI}=0.26-0.43 ; P<0.001)$. Treatment with tylosin did not significantly decrease the incidence of new infection $(\mathrm{RR}=1.08 ; 95 \% \mathrm{CI}=0.84-1.38 ; P=$ $0.55)$. The incidence of new IMI declined with increasing interval between enrollment and calving and with increasing teat height (Table 5). There were no significant interactions present in this model.

The incidence of new IMI with Strep. uberis in the control group was $7.8 \%$. There was a significant interaction between infusion of the teat sealant and precalving IMI status in this model $(P=0.049)$. Teat sealant de- 
Table 2. Number (n) and percentages (\%; within treatment) of bacterial species isolates from the glands sampled by 0 and $5 \mathrm{~d}$ after calving ( $\mathrm{n}=4,164$ glands)

\begin{tabular}{|c|c|c|c|c|c|c|c|c|c|c|}
\hline \multirow[b]{2}{*}{ Isolate } & \multicolumn{8}{|c|}{ Treatment $^{1}$} & & \\
\hline & $\mathrm{n}$ & $\%$ & $\mathrm{n}$ & $\%$ & $\mathrm{n}$ & $\%$ & $\mathrm{n}$ & $\%$ & $\mathrm{n}$ & $\%$ \\
\hline Staphylococcus aureus & 7 & 0.7 & 4 & 0.4 & 4 & 0.4 & 7 & 0.7 & 22 & 0.5 \\
\hline CNS & $41[5]$ & 4.0 & $131[19]$ & 12.6 & $58[11]$ & 5.5 & $134[26]$ & 13.0 & 364 [61] & 8.8 \\
\hline Other major pathogen ${ }^{3}$ & $4[1]$ & 0.4 & $8[2]$ & 0.8 & $5[3]$ & 0.5 & $13[2]$ & 1.3 & $30[9]$ & 0.7 \\
\hline Contaminated & 5 & 0.5 & 9 & 0.9 & 3 & 0.3 & 5 & 0.5 & 22 & 0.5 \\
\hline Total IMI & 77 & 7.5 & 259 & 24.9 & 97 & 9.2 & 255 & 24.7 & 688 & 16.6 \\
\hline Total & 1,028 & & 1,048 & & 1,052 & & 1,036 & & 4,164 & \\
\hline
\end{tabular}

${ }^{1}$ Glands were infused with an intramammary teat sealant into all 4 glands (teat sealant; Teat Seal, Pfizer Animal Health NZ Ltd., Auckland, New Zealand), or treated with injectable tylosin (5 g for 3 d at 24-h intervals; Tylan 200, Elanco Animal Health, Manukau City, New Zealand), or treated with injectable tylosin ( $5 \mathrm{~g}$ for $3 \mathrm{~d}$ at 24 -h intervals) and infused with an intramammary teat sealant into all 4 glands (teat sealant and tylosin) or nothing (control).

${ }^{2}$ Values in brackets indicate the number of glands from which this species was isolated as the second isolate from that gland.

${ }^{3}$ Other major pathogens = Streptococcus dysgalactiae, Streptococcus agalactiae, Klebsiella spp., Pasturella spp., Enterococcus spp., and Escherichia coli.

${ }^{4}$ Other minor pathogens $=$ Corynebacterium spp., yeasts, gram-negative and gram-positive rods

${ }^{5}$ No growth $=<3$ colonies cultured or Bacillus or fungi.

creased the risk of new infection with Strep. uberis in the quarters with no IMI precalving $(\mathrm{RR}=0.31 ; 95 \%$ $\mathrm{CI}=0.21-0.47 ; P<0.001)$ and in the quarters with an IMI precalving $(\mathrm{RR}=0.14 ; 95 \% \mathrm{CI}=0.06-0.33 ; P<$ 0.001 ); however, the preventive effect was stronger in heifers with an IMI precalving. Tylosin did not decrease the incidence of a new IMI with Strep. uberis $(\mathrm{RR}=$ $1.23 ; 95 \%$ CI $=0.88-1.7 ; P=0.22$; Table 5).

\section{Effect of Treatment on Incidence of Clinical Mastitis}

The cumulative incidence of clinical mastitis in the control group in the period up to $14 \mathrm{~d}$ postcalving was $6.6 \%$ (Table 3). The most common species isolated from clinical mastitis cases was Strep. uberis $(56.5 \%$ of all clinical mastitis cases from the control group; Table 3 ).

Teat sealant did not alter the incidence of clinical mastitis [143/2,084 (6.9\%) vs. $164 / 2,080$ (7.9\%); RR =

Table 3. Number (n) and percentage (\%; within treatment) of bacterial species isolated from glands diagnosed with clinical mastitis $14 \mathrm{~d}$ postcalving

\begin{tabular}{|c|c|c|c|c|c|c|c|c|c|c|}
\hline \multirow[b]{3}{*}{ Isolate } & \multicolumn{8}{|c|}{ Treatment $^{1}$} & & \\
\hline & \multicolumn{2}{|c|}{ Teat sealant } & \multicolumn{2}{|c|}{ Tylosin } & \multicolumn{2}{|c|}{ Teat sealant and tylosin } & \multicolumn{2}{|c|}{ Control } & \multicolumn{2}{|c|}{ Total } \\
\hline & $\mathrm{n}$ & $\%$ & $\mathrm{n}$ & $\%$ & $\mathrm{n}$ & $\%$ & $\mathrm{n}$ & $\%$ & $\mathrm{n}$ & $\%$ \\
\hline Streptococcus uberis & 9 & 15.0 & 51 & 68.9 & 8 & 7.9 & 39 & 56.5 & 107 & 35 \\
\hline Staphylococcus aureus & 3 & 5.0 & 1 & 1.4 & 2 & 2.0 & 2 & 2.9 & 8 & \\
\hline CNS & $4[1]^{2}$ & 6.7 & $10[1]$ & 13.5 & $7[2]$ & 6.9 & $10[2]$ & 14.5 & $31[6]$ & 10 \\
\hline Other major pathogens ${ }^{3}$ & 0 & 0.0 & 3 & 4.1 & 1 & 1.0 & $7[1]$ & 10.1 & $11[1]$ & \\
\hline No growth ${ }^{4}$ & 45 & 75.0 & 10 & 13.5 & 85 & 84.2 & 14 & 20.3 & 154 & 50. \\
\hline Contaminated & 0 & 0.0 & 0 & 0.0 & 3 & 2.9 & 0 & 0.0 & 3 & \\
\hline Total bacteria-positive & 16 & 26.7 & 65 & 87.8 & 18 & 17.8 & 58 & 84.1 & 157 & 51.6 \\
\hline Total clinical quarters ${ }^{5}$ & 60 & & 74 & & 104 & & 69 & & 307 & \\
\hline
\end{tabular}

${ }^{1}$ Glands were infused with an intramammary teat sealant into all 4 glands (teat sealant; Teat Seal, Pfizer Animal Health NZ Ltd., Auckland, New Zealand), or treated with injectable tylosin (5 g for $3 \mathrm{~d}$ at 24-h intervals; Tylan 200, Elanco Animal Health, Manukau City, New Zealand), or treated with injectable tylosin ( $5 \mathrm{~g}$ for $3 \mathrm{~d}$ at 24 -h intervals) and infused with an intramammary teat sealant into all 4 glands (teat sealant and tylosin) or nothing (control).

${ }^{2}$ Values in brackets indicate the number of glands from which this species was isolated as the second isolate from that gland.

${ }^{3}$ Other major pathogens = Streptococcus dysgalactiae, Streptococcus agalactiae, Klebsiella spp., Pasturella spp., Enterococcus spp., and Escherichia coli.

${ }^{4}$ No growth $=<3$ colonies cultured or Bacillus or fungi.

${ }^{5}$ Total number of quarters diagnosed with clinical mastitis by the farmer. 
Table 4. Gland level relative risk (RR), 95\% confidence intervals (CI) and probability $(P)$ of postcalving IMI for heifers treated with injectable tylosin or infusion of an intramammary teat sealant into all 4 glands approximately $27 \mathrm{~d}$ precalving

\begin{tabular}{|c|c|c|c|c|c|c|c|}
\hline \multirow[b]{2}{*}{ Variable } & \multirow[b]{2}{*}{ Category } & \multirow[b]{2}{*}{ Estimate } & \multirow[b]{2}{*}{ SE } & \multirow[b]{2}{*}{$\mathrm{RR}$} & \multicolumn{2}{|c|}{$95 \% \mathrm{CI}$} & \multirow[b]{2}{*}{$P$-value } \\
\hline & & & & & Lower & Upper & \\
\hline Intercept & & 0.44 & 0.74 & & & & 0.55 \\
\hline Teat sealant & & -1.05 & 0.11 & 0.35 & 0.28 & 0.44 & $<0.001$ \\
\hline Tylosin & & 0.02 & 0.11 & 1.02 & 0.82 & 1.27 & 0.84 \\
\hline Prealving IMI & & 1.18 & 0.07 & 3.25 & 2.82 & 3.74 & $<0.001$ \\
\hline \multirow[t]{2}{*}{ Breed } & Friesian & 0.28 & 0.16 & 1.33 & 0.97 & 1.82 & 0.08 \\
\hline & $\begin{array}{l}\text { Jersey } \\
\text { Crossbred }^{1}\end{array}$ & -0.41 & 0.16 & 0.67 & 0.48 & 0.92 & 0.01 \\
\hline \multirow[t]{4}{*}{ BCS } & $<4.5$ & -0.52 & 0.28 & 0.60 & 0.35 & 1.03 & 0.06 \\
\hline & 4.5 & -0.58 & 0.23 & 0.51 & 0.32 & 0.81 & 0.04 \\
\hline & 5 & -0.41 & 0.20 & 0.66 & 0.45 & 0.98 & 0.04 \\
\hline & $\begin{array}{c}5.5 \\
>5.5^{1}\end{array}$ & -0.24 & 0.20 & 0.79 & 0.53 & 1.17 & 0.24 \\
\hline Calving to sampling $(\mathrm{d})^{2}$ & & -0.27 & 0.05 & 0.76 & 0.70 & 0.84 & $<0.001$ \\
\hline Minimum teat height $(\mathrm{cm})^{3}$ & & -0.04 & 0.01 & 0.96 & 0.94 & 0.99 & 0.01 \\
\hline Herd $^{4}$ & & 0.08 & & & & & \\
\hline Cow nested within herd ${ }^{4}$ & & 1.6 & & & & & \\
\hline
\end{tabular}

${ }^{1}$ Reference category.

${ }^{2}$ Interval between calving and postcalving sampling ( 0 to $5 \mathrm{~d}$ ).

${ }^{3}$ Minimum teat end height from the ground $(\mathrm{cm})$.

${ }^{4}$ Random effect terms in model.

$1.2 ; 95 \%$ CI $=0.93-1.4 ; P=0.20]$. Teat sealant did, however, decrease the incidence of clinical mastitis from which a bacterial pathogen was isolated [34/2,080 $(1.6 \%)$ vs. $130 / 2,084(6.2 \%)]$. A borderline significant interaction between precalving IMI and infusion of teat sealant was present $(P=0.06)$. This interaction was similar to that present in the multivariate model for the outcome of new IMI with Strep. uberis. Teat sealant decreased the risk of clinical mastitis in quarters from which a bacterial pathogen was isolated in the quarters with no IMI precalving $(\mathrm{RR}=0.30 ; 95 \% \mathrm{CI}=0.19-0.47$; $P<0.001)$ and in the quarters with an IMI precalving $(\mathrm{RR}=0.21 ; 95 \% \mathrm{CI}=0.12-0.35 ; P<0.001 ;$ Figure 2$)$, indicating a stronger preventive effect in quarters with

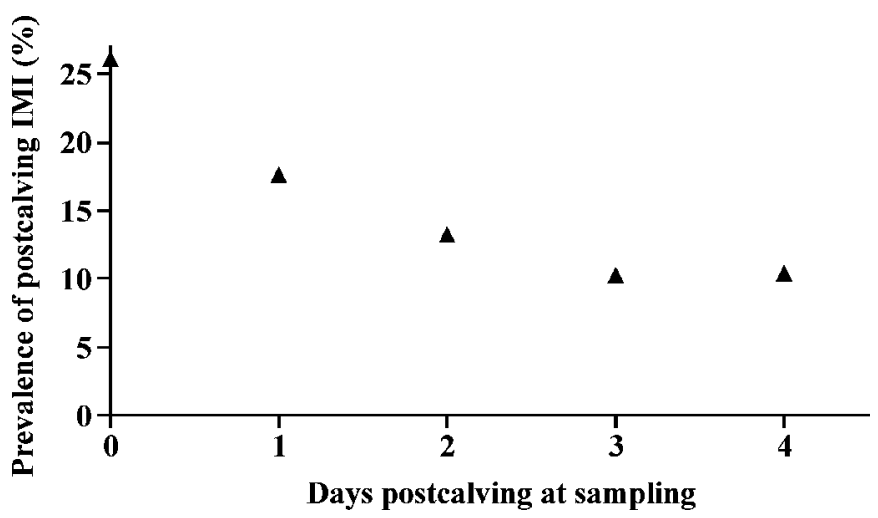

Figure 1. Prevalence of glands with IMI postcalving (\%) by day at sampling. an IMI precalving. Tylosin did not decrease the incidence of clinical mastitis from which a bacterial pathogen was isolated $(\mathrm{RR}=1.01 ; 95 \% \mathrm{CI}=0.66-1.52 ; P=$ 0.98; Table 6).

The number of clinical mastitis cases from which no bacterial pathogen was isolated was greater in the glands treated with teat sealant compared with the control glands [130/164 (79.3\%) vs. $24 / 143(16.8 \%) ; \mathrm{RR}=$ $4.7 ; 95 \% \mathrm{CI}=3.3-6.9 ; P<0.001 ;$ Table 3$]$.

\section{DISCUSSION}

This study demonstrated that infusion of a teat sealant into quarters approximately $39 \mathrm{~d}$ precalving reduced the risk of new IMI by $66 \%$, reduced postcalving prevalence of IMI by $65 \%$, and reduced the incidence of clinical mastitis from which any pathogen was isolated by $74 \%$. Use of an internal teat sealant offers a preventative approach to heifer mastitis, and with better producer understanding of this product, the use of antimicrobial agents for mastitis may be reduced.

Parenteral treatment with tylosin had no effect on cure of existing IMI, prevalence of IMI postcalving, or on incidence of clinical mastitis.

This study was performed using 1,067 heifers in 30 spring-calving, pasture-fed dairy herds. The herdowners, although selected primarily on their ability to collect high-quality cow records and their commitment to comply with trial protocol, managed commercial dairy farms. The individual herd differences in response to the treatments were not of primary importance, and 
Table 5. Gland level relative risk (RR) and 95\% confidence intervals (CI) for new IMI with any pathogen between approximately $39 \mathrm{~d}$ precalving and 0 to 5 postcalving in heifers treated with injectable tylosin or infusion of an intramammary teat sealant into all 4 glands, approximately $27 \mathrm{~d}$ precalving

\begin{tabular}{lcccccc}
\hline & & & & \multicolumn{2}{c}{$95 \%$ CI } & \\
Variable & Estimate & $\mathrm{SE}$ & $\mathrm{RR}$ & Lower & Upper & $P$-value \\
\hline Intercept & -0.55 & 0.74 & & & & 0.47 \\
Teat sealant & -1.09 & 0.13 & 0.34 & 0.26 & 0.43 & $<0.001$ \\
Tylosin & 0.07 & 0.12 & 1.08 & 0.84 & 1.38 & 0.55 \\
Calving to sampling $(\mathrm{d})^{1}$ & -0.26 & 0.05 & 0.77 & 0.70 & 0.86 & $<0.001$ \\
${\text { Minimum teat height }(\mathrm{cm})^{2}}_{\text {Herd }^{3}}$ & -0.03 & 0.01 & 0.97 & 0.95 & 1.00 & 0.05 \\
Cow nested within herd $^{3}$ & & 0.16 & & & & \\
\hline
\end{tabular}

\footnotetext{
${ }^{1}$ Interval between calving and postcalving sampling ( 0 to $\left.5 \mathrm{~d}\right)$.

${ }^{2}$ Minimum teat and height from the ground $(\mathrm{cm})$.

${ }^{3}$ Random effect terms in model; herd is the variance adjusted for the correlation of cows within herd; cow nested within herd is the variance adjusted for the correlation of quarters within cow.
}

herd was included as a random effect in the analysis. Therefore, care must be taken in extrapolation of the results to other dairy systems with different management practices, and with different proportions of the various mastitis pathogens.

The initial hypotheses were that antibiotic treatment would cure existing precalving IMI, infusion of an inert teat-canal sealant would reduce new IMI, and that their action may be additive in decreasing postcalving IMI and clinical mastitis. Therefore, despite the treatments being administered at the heifer level, the data analysis was performed at the gland level in an attempt to understand the proposed mechanism of action of the treatments.

It is likely that teat sealant was acting as a physical barrier within the teat canal, reducing the risk of bacterial invasion, and hence reducing the risk of a new IMI

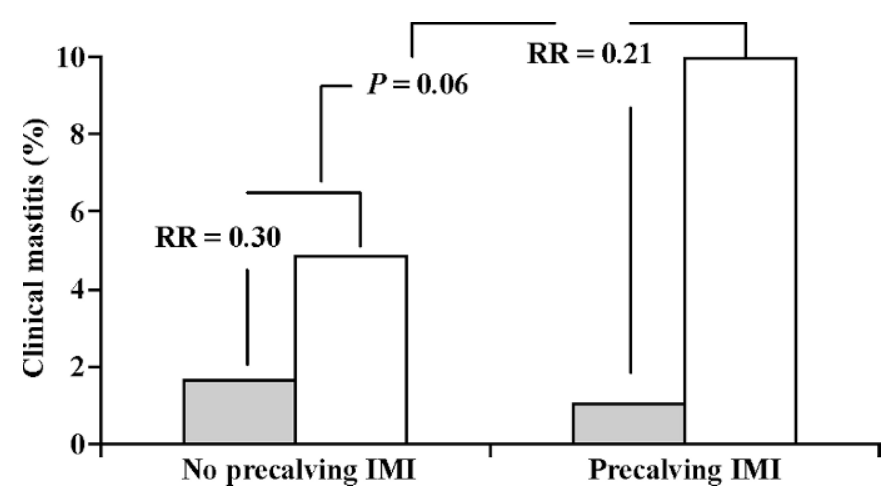

Figure 2. Raw gland-level incidence of clinical mastitis (\%) occurring within the first $14 \mathrm{~d}$ after calving that cultured any pathogen by treatment [infusion of all glands with teat sealant (gray; Teat Seal, Pfizer Animal Health NZ Ltd., Auckland, New Zealand) or untreated glands (white)], stratified by the precalving IMI status for each gland. (RR $=$ relative risk; $P=0.06$ is the type $\mathrm{I}$ error for the difference between strata).
(Meaney, 1977; Woolford et al., 1998). The effect of a teat sealant probably continues until the sealant is physically stripped (human) or sucked (calf) from the gland (Woolford et al., 1998; Berry and Hillerton, 2002a; Huxley et al., 2002). This means the sealant is likely present in the canal during most of the high-risk period; that is, including the few days before calving (Aarestrup and Jensen, 1997). Teat sealants have been used extensively at the end of lactation in cows, and the new dryperiod IMI rate was reduced by $94 \%$ in the treated cows (Woolford et al., 1998). The new IMI at calving was reduced by $65 \%$ in cows treated at drying off with teat sealant compared with no treatment at drying (Berry and Hillerton, 2002a), by $30 \%$ in quarters treated with intramammary antibiotics and a teat sealant compared with quarters only treated with an intramammary antibiotic at drying off (Godden et al., 2003), and by 50\% in cows treated with intramammary antibiotics and a teat sealant compared with cows treated only with an intramammary antibiotic at drying off (Berry and Hillerton, 2007). Similarly, in the current study, the teat sealant decreased the risk of new IMI with any pathogen by $66 \%$ and with Strep. uberis by $73 \%$. The prevalence of Strep. uberis in the control group increased from $32 / 1,036$ (3.3\%) approximately $39 \mathrm{~d}$ precalving to $98 / 1,036(9.5 \%) 0$ to $5 \mathrm{~d}$ postcalving, illustrating the high rate of new IMI occurring with Strep. uberis over this period. Streptococcus uberis was the most commonly isolated pathogen from clinical mastitis cases in this study, consistent with other New Zealand studies (Pankey et al., 1996; McDougall, 1999).

In the current study the use of a teat sealant decreased the risk of clinical mastitis from which a pathogen was isolated, but did not decrease the risk of farmerdiagnosed clinical mastitis. This apparent discrepancy is most likely caused by false-positive diagnosis of clinical mastitis in some animals infused with the teat seal- 
Table 6. Gland level relative risk (RR) and 95\% confidence intervals (CI) of glands being diagnosed with clinical mastitis up to $14 \mathrm{~d}$ postcalving from which bacterial pathogens were isolated in heifers treated with injectable tylosin or infusion of an intramammary teat sealant into all 4 glands, approximately $27 \mathrm{~d}$ precalving

\begin{tabular}{lcccccc}
\hline & & & & \multicolumn{2}{c}{$95 \%$ CI } & \\
Variable & Estimate & SE & RR & Lower & Upper & $P$-value \\
\hline Intercept & -4.75 & 0.18 & 0.01 & & & $<0.001$ \\
Teat sealant & -1.20 & 0.23 & 0.30 & 0.19 & 0.47 & $<0.001$ \\
Tylosin & 0.01 & 0.21 & 1.01 & 0.66 & 1.52 & 0.98 \\
Precalving IMI & 0.84 & 0.09 & 2.31 & 1.92 & 2.76 & $<0.001$ \\
Teat sealant $\times$ precalving IMI ${ }^{1}$ & -0.38 & 0.21 & 0.68 & 0.46 & 1.02 & 0.06 \\
IMI present precalving $_{\text {IMI absent precalving }}$ & -1.58 & & 0.30 & & & \\
Herd $^{2}$ & -1.20 & & 0.21 & & & \\
Cow nested within herd $^{2}$ & & 0.13 & & & & \\
\hline
\end{tabular}

${ }^{1}$ Interaction term.

${ }^{2}$ Random effect terms in model; herd is the variance adjusted for the correlation of cows within herd; cow nested within herd is the variance adjusted for the correlation of quarters within cow.

ant. Nearly $80 \%$ of milk samples from clinical mastitis cases from glands infused with teat sealant had no pathogen isolated from them. In contrast, only $17 \%$ of samples from glands diagnosed with clinical mastitis from glands not infused with teat sealant failed to isolate a pathogen, which is consistent with previous studies investigating clinical mastitis in New Zealand (McDougall, 1999). This difference between the treatment and control groups, in the frequency of clinical mastitis cases with no bacteria isolated, demonstrates a misclassification bias; hence, it is reasonable to report clinical mastitis with any pathogen isolated as an outcome variable because it is free from this bias. The greater proportion of samples from clinical mastitis cases with no growth following treatment with the teat sealant was consistent with a previous study (Parker et al., 2007). It is hypothesized that some farmers interpreted presence of fragments of teat sealant in the treated glands postcalving as evidence of clinical mastitis. The trial clearly demonstrated that the difference in treatment effect between all clinical mastitis cases and clinical mastitis with bacterial isolation was the result of an observation bias that was most likely due to the effect of the teat sealant on the discoloring of milk or the presence of fragments of teat sealant in the milk being interpreted by farmers as clots. Farmer diagnosis was used to maintain a high level of external validity in the study because, in New Zealand, farmers undertake the majority of diagnosis of clinical mastitis. Because the costs of treating cows with antibiotics and milk discard are significant, the number of false-positive diagnoses of clinical mastitis needs to be minimized. Hence, farmers using teat sealant need to be made aware of this potential diagnostic problem. In the future, with better producer understanding, the use of antimicrobial agents for clinical mastitis may be re- duced in herds following the use of teat sealant precalving.

Previous studies have emphasized the need for aseptic technique during application of the teat sealant (Woolford et al., 1998; Huxley et al., 2002). In this study the technicians were fastidious about hygiene and there were no adverse effects such as clinical mastitis or systemically ill animals following infusion of the teat sealant.

Infusion of intramammary antibiotics (both lactating and dry cow formulations) in heifers precalving (Oliver et al., 1992, 1997), resulted in cure of existing IMI and led to a decrease in the prevalence of postcalving IMI, reduced clinical mastitis incidence, and reduced SCC during the subsequent lactation. Anecdotal reports suggest that use of injectable antibiotics peripartum in heifers results in decreased postcalving IMI. Additionally, injectable antibiotics have been shown to result in similar bacteriological cure rates as intramammary antibiotics for treating clinical and subclinical mastitis in lactating cows (St-Rose et al., 2003; McDougall et al., 2007). Because of the seasonal calving pattern and large herd size in New Zealand, precalving treatment of heifers may need to be able to be applied to groups of $>50$ animals. Parenteral treatment alone may be more feasible than intramammary therapy under these management systems.

Tylosin treatment precalving did not alter the cure proportion, the prevalence of postcalving IMI, or the incidence of clinical mastitis. Possible reasons for this include the failure of the tylosin to exceed MIC for sufficient duration in nonlactating animals, inherent or acquired resistance of the pathogens present to tylosin, or that cure did occur but that the gland became reinfected before postcalving sampling. 
The dose and route of administration followed the New Zealand label directions for tylosin in lactating cows. Tylosin is a member of the macrolide antibiotic family and acts by inhibiting RNA-dependent protein synthesis by blocking translation at the ribosome. Macrolides are generally highly effective against gram-positive cocci (both Staphylococcus and Streptococcus spp.), and moderately effective against Enterococcus spp., but have a poor action against gram-negative bacteria (Salmon et al., 1998). In the current study, CNS were the most commonly isolated species precalving. Some New Zealand CNS isolates have been reported to be resistant to some antibiotics (Hodges et al., 1984; Salmon et al., 1998). Salmon et al. (1998) reported that erythromycin (also a member of the macrolide family) was effective against Staphylococcus and Streptococcus spp. isolated from the mammary glands of New Zealand and Danish dairy heifers. The range of efficacy was, however, between $\mathrm{MIC}_{90}=0.13$ to $64 \mu \mathrm{g} / \mathrm{mL}$, indicating that there was some resistance within these bacterial species.

Tylosin is a weak base, and therefore reaches greater concentrations in milk than in serum because of the low $\mathrm{pH}$ of milk compared with serum (Ziv, 1980). In heifers precalving, lactogenesis is limited; hence, it is likely that the $\mathrm{pH}$ of the secretion from the mammary gland is similar to that of serum. In this situation, the concentration of tylosin is unlikely to reach the same concentrations as in the lactating gland, resulting in lower cure rates.

Failure of bacteriological cure, as defined in the current study, may have occurred if a gland underwent bacteriological cure, but was subsequently reinfected with the same pathogen species. Molecular typing methods would be able to determine if this was occurring, but were not used in this study. Presence of keratin within the teat canal (a teat plug) has been shown to reduce the risk of new IMI in multiparous cows over the nonlactating period (Williamson et al., 1995). Presence of an IMI precalving may indicate the total absence of, or ineffectiveness of, the teat plug. Lack of an effective teat plug may increase the risk of an IMI precalving and increase the risk of reinfection following antibiotic therapy.

Use of intramammary antibiotics that were designed for lactating cows in heifers precalving does not meet the guidelines of the New Zealand regulatory authority (Agricultural Compounds in Veterinary Medicine). Intramammary infusion of antibiotics precalving in heifers results in a proportion of milk samples collected postcalving containing detectable concentrations of antibiotics in some (Trinidad et al., 1990b; Oliver et al., 1992), but not all (Owens et al., 1994), studies. Antibiotic residues were not measured in this study, but time from treatment to calving was estimated to comply with recommended withholding times and none of the milk from any of the heifers was sent for commercial supply until at least 10 milkings after calving. Evaluation of concentrations of antibiotics in milk following parenteral therapy administered precalving is required before commercial use.

In the present study, precalving IMI was associated with an increased risk of postcalving IMI and clinical mastitis, in agreement with the previous heifer study of Strep. dysgalactiae (Aarestrup and Jensen, 1997) and over all bacterial species (Parker et al., 2007). The presence of an interaction between precalving IMI and the efficacy of the teat sealant indicated that it is not that the teat sealant is more effective when an IMI is present precalving, but rather that glands with a precalving IMI are at greater risk of new IMI in the absence of teat sealant. There seemed to be a difference in the incidence of new IMI with Strep. uberis or the incidence of clinical mastitis from which a pathogen was isolated following the use of teat sealant with a precalving IMI compared with no precalving IMI. This may be explained using the hypothesis that glands with an open teat canal and consequently presence of an existing precalving IMI were at increased risk of new infection with another pathogen compared with glands with no precalving IMI. At the bivariate level, the interaction was significant for all outcomes tested. Studies using teat sealant at drying off in lactating cows did not find an interaction between teat sealant and IMI at drying off in the risk of postcalving IMI and clinical mastitis (Huxley et al., 2002; Godden et al., 2003). Huxley et al. (2002), however, used teat sealant only in a subset of quarters (low SCC), and Godden et al. (2003) treated every quarter with teat sealant and antibiotics. Quarters with low SCC may be predisposed to fewer new IMI, and treating quarters with antibiotics changes the bacterial population of the canal and therefore may affect the incidence of new IMI, such that an interaction between teat sealant and IMI status at treatment was not identified.

The effect of precalving IMI on new IMI in cows is uncertain. Some studies performed during lactation indicate that glands previously infected with minor pathogens, in particular CNS (Rainard and Poutrel, 1988; Matthews et al., 1991) or Corynebacterium bovis, were more resistant to new IMI than uninfected glands (Rainard and Poutrel, 1988; Lam et al., 1997). The relative protectiveness of precalving IMI with $C$. bovis vs. CNS is not well understood and is inconsistent between studies (Rainard and Poutrel, 1988; Lam et al., 1997). The effect of an existing Corynebacterium spp. infection on the risk of a new IMI is unclear. Some studies (Rainard and Poutrel, 1988; Lam et al., 1997) have indicated 
that Corynebacterium spp. is protective against subsequent major-pathogen IMI, whereas others have found the opposite effect (Pankey et al., 1985; Hogan et al., 1988). The stage of lactation may be important because Corynebacterium spp. present at drying off increased, whereas Corynebacterium spp. present in late gestation and early lactation reduced, the risk of new IMI (Green et al., 2002). Berry and Hillerton (2002b) also demonstrated that IMI at drying off with CNS or with Corynebacterium spp. increased the risk of new IMI at calving with Strep. uberis or E. coli.

Recent in vitro work has shown that Staphylococcus chromogenes taken from the teat apex of heifers consistently inhibited the growth of Staph. aureus, Strep. dysgalactiae, and Strep. uberis (De Vliegher et al., 2004). The current study and a previous study (Parker et al., 2007) found that presence of any IMI did not protect quarters against all or major-pathogen new IMI, but increased the risk of IMI postcalving. The majority of precalving IMI in both of these studies were CNS $(77.5 \%)$. Why these effects were strong in heifers precalving, but variable in lactating cows requires further examination. One limitation of the current study was that no speciation was performed on the CNS isolates; hence, it is unclear whether the postcalving isolate was the same infection or a new infection of CNS. Based on the results from the current study, reduction in the prevalence of precalving IMI is likely to result in reduced prevalence of IMI postcalving and incidence of clinical mastitis in heifers.

It has been shown that the risk of IMI for glands within a cow is not independent (Barkema et al., 1997); that is, clustering occurs. Statistical techniques to deal with nonindependence of glands have been developed including the use of random effects terms in models (McDermott et al., 1994). In this study, the calculated ICC between glands was moderate. Mixed effects models with random effect terms for herd and cow nested within herds that accounted for correlation within cow and herd were used, with the correlation within cow (for postcalving IMI ICC $=0.31$ ) being far greater than correlation within herd (for postcalving IMI ICC $=0.08$ ). Thus, risk factors operating at the animal level appear to be more important than those operating at the herd level, indicating that future interventions should focus at the cow rather than the herd level. The ICC from the current study are similar to those previously reported (Barkema et al., 1997). The degree of clustering within cow or within herds may, however, be dependent on the bacterial pathogens present and the types of management systems operating. For example, it may be expected that contagious pathogens such as Staph. aureus would have greater within-cow clustering com- pared with environmental pathogens such as Strep. $u b$ eris (Barkema et al., 1997; Zadoks et al., 2001).

\section{CONCLUSIONS}

The current study demonstrated that infusion of an internal teat sealant precalving in heifers is effective in reducing the prevalence of IMI at calving and the frequency of clinical mastitis cases postcalving from which bacteria were isolated. This nonantibiotic approach presents a novel and practical option for producers wishing to reduce mastitis in their heifers postcalving. The absence of interactions with the known covariates such as breed, herd, udder edema, and BCS are important, because this indicates that the effect of teat sealant will be consistent for use in a range of herd and heifer types. Parenteral treatment with a macrolide antibiotic failed to reduce the new IMI, reduce the prevalence of IMI postcalving, or reduce the incidence of clinical mastitis postcalving. Presence of an IMI precalving was, however, an important risk factor for postcalving IMI and clinical mastitis; thus, methods to reduce prevalence of IMI precalving require further investigation in heifers.

\section{ACKNOWLEDGMENTS}

The technical assistance of Kathryn Berry, Elizabeth Blythe, Rhonda Cooper, Judith Forno, Mike Kingstone, and Shelley Roberts for their work on farms and in the laboratory is gratefully acknowledged. The involvement and patience of the herd owners is gratefully acknowledged. Farmer levy funds (Dairy Insight, New Zealand) and Elanco Animal Health (Auckland, New Zealand) funded this study.

\section{REFERENCES}

Aarestrup, F. M., and N. E. Jensen. 1997. Prevalence and duration of intramammary infection in Danish heifers during the peripartum period. J. Dairy Sci. 80:307-312.

Barkema, H. W., Y. H. Schukken, T. J. Lam, M. L. Beiboer, H. Wilmink, G. Benedictus, and A. Brand. 1998. Incidence of clinical mastitis in dairy herds grouped in three categories by bulk milk somatic cell counts. J. Dairy Sci. 81:411-419.

Barkema, H. W., Y. H. Schukken, T. J. Lam, D. T. Galligan, M. L. Beiboer, and A. Brand. 1997. Estimation of interdependence among quarters of the bovine udder with subclinical mastitis and implications for analysis. J. Dairy Sci. 80:1592-1599.

Barnouin, J., and M. Chassagne. 2001. Predictive variables for the occurrence of early clinical mastitis in primiparous Holstein cows under field conditions in France. Can. Vet. J. 42:47-53.

Berry, E. A., and J. E. Hillerton. 2002a. The effect of an intramammary teat seal on new intramammary infections. J. Dairy Sci. 85:2512-2520.

Berry, E. A., and J. E. Hillerton. 2002b. The effect of selective dry cow therapy on new intramammary infections. J. Dairy Sci. $85: 112-121$

Berry, E. A., and J. E. Hillerton. 2007. Effect of an intramammary teat seal and dry cow antibiotic in relation to dry period length on postpartum mastitis. J. Dairy Sci. 90:760-765. 
De Vliegher, S., G. Opsomer, A. Vanrolleghem, L. A. Devriese, O. C. Sampimon, J. Sol, H. W. Barkema, F. Haesebrouck, and A. de Kruif. 2004. In vitro growth inhibition of major mastitis pathogens by Staphylococcus chromogenes originating from teat apices of dairy heifers. Vet. Microbiol. 101:215-221.

Dohoo, I., W. Martin, and H. Stryhn. 2003. Veterinary Epidemiologic Research. AVC Inc., Charlottetown, Canada.

Godden, S., P. Rapnicki, S. Stewart, J. Fetrow, A. Johnson, R. Bey, and R. Farnsworth. 2003. Effectiveness of an internal teat seal in the prevention of new intramammary infections during the dry and early-lactation periods in dairy cows when used with a dry cow intramammary antibiotic. J. Dairy Sci. 86:3899-3911.

Green, M. J., L. E. Green, G. F. Medley, Y. H. Schukken, and A. J. Bradley. 2002. Influence of dry period bacterial intramammary infection on clinical mastitis in dairy cows. J. Dairy Sci. 85:2589-2599.

Hintze, J. 2001. Number Cruncher Statistical Software and Power Analysis Statistical Software. Kaysville, UT.

Hodges, R. T., Y. S. Jones, and J. T. S. Holland. 1984. Characterization of staphylococci associated with clinical and subclinical bovine mastitis. N. Z. Vet. J. 32:141-145.

Hogan, J. S., K. L. Smith, D. A. Todhunter, and P. S. Schoenberger. 1988. Rate of environmental mastitis in quarters infected with Corynebacterium bovis and Staphylococcus species. J. Dairy Sci. $71: 2520-2525$

Huxley, J. N., M. J. Green, L. E. Green, and A. J. Bradley. 2002. Evaluation of the efficacy of an internal teat sealer during the dry period. J. Dairy Sci. 85:551-561.

Lam, T. J. G. M., Y. H. Schukken, J. H. vanVliet, F. J. Grommers, M. J. M. Tielen, and A. Brand. 1997. Effect of natural infection with minor pathogens on susceptibility to natural infection with major pathogens in the bovine mammary gland. Am. J. Vet. Res. $58: 17-22$.

Matthews, K. R., R. J. Harmon, and B. E. Langlois. 1991. Effect of naturally occurring coagulase-negative staphylococci infections on new infections by mastitis pathogens in the bovine. J. Dairy Sci. 74:1855-1859.

McDermott, J. J., Y. H. Schukken, and M. M. Shoukri. 1994. Study design and analytic methods for data collected from clusters of animals. Prev. Vet. Med. 18:175-191.

McDougall, S. 1999. Prevalence of clinical mastitis in 38 Waikato dairy herds in early lactation. N. Z. Vet. J. 47:143-149.

McDougall, S., K. E. Agnew, R. Cursons, X. X. Hou, and C. R. W. Compton. 2007. Parenteral treatment of clinical mastitis with tylosin base or penethamate hydriodide in dairy cattle. J. Dairy Sci. 90:779-789.

McNutt, L., C. C. Wu, X. Xue, and J. P. Hafner. 2003. Estimating the relative risk in cohort studies and clinical trials of common outcomes. Am. J. Epidemiol. 157:940-943.

Meaney, W. J. 1977. Effect of a dry period teat seal on bovine udder infections. Irish J. Agric. Res. 16:293-299.

Myllys, V. 1995. Staphylococci in heifer mastitis before and after parturition. J. Dairy Res. 62:51-60.

National Mastitis Council. 1999. Laboratory Handbook on Bovine Mastitis. National Mastitis Council, Madison, WI.

Oliver, S. P., M. J. Lewis, B. E. Gillespie, and H. H. Dowlen. 1992. Influence of prepartum antibiotic therapy on intramammary infections in primigravid heifers during early lactation. J. Dairy Sci. 75:406-414.

Oliver, S. P., M. J. Lewis, B. E. Gillespie, and H. H. Dowlen. 1997. Antibiotic residues and prevalence of mastitis pathogen isolation in heifers during early lactation following prepartum antibiotic therapy. J. Vet. Med. 44:213-220.

Oliver, S. P., and B. A. Mitchell. 1983. Intramammary infections in primigravid heifers near parturition. J. Dairy Sci. 66:1180-1185.

Owens, W. E., S. C. Nickerson, P. J. Washburn, and C. H. Ray. 1994. Prepartum antibiotic-therapy with a Cephapirin dry-cow product against naturally-occurring intramammary infections in heifers. J. Vet. Med. Ser. B. 41:90-100.

Pankey, J. W., P. A. Drechsler, and E. E. Wildman. 1991. Mastitis prevalence in primigravid heifers at parturition. J. Dairy Sci. $74: 1550-1552$.

Pankey, J. W., S. C. Nickerson, R. L. Boddie, and J. S. Hogan. 1985. Effects of Corynebacterium bovis infection on susceptibility to major mastitis pathogens. J. Dairy Sci. 68:2684-2693.

Pankey, J. W., P. B. Pankey, R. M. Barker, J. H. Williamson, and M. W. Woolford. 1996. The prevalence of mastitis in primiparous heifers in eleven Waikato dairy herds. N. Z. Vet. J. 44:41-44.

Parker, K. I., C. Compton, F. M. Anniss, A. Weir, C. Heuer, and S. McDougall. 2007. Subclinical and clinical mastitis in heifers following the use of a teat sealant pre-calving. J. Dairy Sci. 90:207-218.

R Development Core Team. 2006. R: A language and environment for statistical computing. 2.4.0 ed. R Foundation for Statistical Computing, Vienna, Austria.

Rainard, P., and B. Poutrel. 1988. Effect of naturally occurring intramammary infections by minor pathogens on new infections by major pathogens in cattle. Am. J. Vet. Res. 49:327-329.

Roche, J. R., P. G. Dillon, C. R. Stockdale, L. H. Baumgard, and M. J. Van Baale. 2004. Relationships among international body condition scoring systems. J. Dairy Sci. 87:3076-3079.

Salmon, S. A., J. L. Watts, F. M. Aarestrup, J. W. Pankey, and R. J. J. Yancey. 1998. Minimum inhibitory concentrations for selected antimicrobial agents against organisms isolated from the mammary glands of dairy heifers in New Zealand and Denmark. J. Dairy Sci. 81:570-578.

Schreiner, D. A., and P. L. Ruegg. 2003. Relationship between udder and leg hygiene scores and subclinical mastitis. J. Dairy Sci. 86:3460-3465.

Sears, P. M., B. S. Smith, P. B. English, P. S. Herer, and R. N. Gonzalez. 1990. Shedding pattern of Staphylococcus aureus from bovine mammary infections. J. Dairy Sci. 72:1900-1906.

St-Rose, S. G., J. M. Swinkels, W. D. J. Kremer, C. L. J. J. Kruitwagen, and R. N. Zadoks. 2003. Effect of penethamate hydriodide treatment on bacteriological cure, somatic cell count and milk production of cows and quarters with chronic subclinical Streptococcus uberis or Streptococcus dysgalactiae infection. J. Dairy Res. 70:387-394.

Trinidad, P., S. C. Nickerson, and T. K. Alley. 1990a. Prevalence of intramammary infection and teat canal colonization in unbred and primigravid dairy heifers. J. Dairy Sci. 73:107-114.

Trinidad, P., S. C. Nickerson, T. K. Alley, and R. W. Adkinson. 1990b. Efficacy of intramammary treatment in unbred and primigravid dairy heifers. J. Dairy Sci. 197:465-470.

Williamson, J. H., M. W. Woolford, and A. M. Day. 1995. The prophylactic effect of a dry-cow antibiotic against Streptococcus uberis. N. Z. Vet. J. 43:228-234.

Woolford, M. W., I. S. Hook, M. T. Eden, and A. K. Joe. 1995. The "SAMM PLAN" a seasonal approach to managing mastitis. Pages 59-63 in Proc. 3rd IDF International Mastitis Seminar, Tel Aviv, Israel. National Mastitis Reference Center, Kimron Vet. Inst., Bet Dagan, Israel.

Woolford, M. W., J. H. Williamson, A. M. Day, and P. J. Copeman. 1998. The prophylactic effect of a teat sealer on bovine mastitis during the dry period and the following lactation. N. Z. Vet. J. 46:12-19.

Zadoks, R. N., H. G. Allore, H. W. Barkema, O. C. Sampimon, G. J. Wellenberg, Y. T. Grohn, and Y. H. Schukken. 2001. Cow- and quarter-level risk factors for Streptococcus uberis and Staphylococcus aureus mastitis. J. Dairy Sci. 84:2649-2663.

Ziv, G. 1980. Practical pharmacokinetic aspects of mastitis therapy 2. Practical and therapeutic applications. Vet. Med. Small Anim. Clin. 75:469-474.

Ziv, G., and M. Storper. 1985. Intramuscular treatment of subclinical staphylococcal mastitis in lactating cows with penicillin G, methicillin and their esters. J. Vet. Pharmacol. Ther. 8:276-283. 